Vol. 4, No. 4, 2019

\title{
URANIUM MINING AND MILLING FACILITIES LEGACY SITES: UKRAINE CASE STUDY
}

\author{
Tamara Dudar \\ National Aviation University, \\ Department of Environmental Studies, \\ Faculty of Environmental Safety, Engineering and Technologies, \\ 1, Komarov Avenue, Kyiv, 03058, Ukraine \\ dudar@nau.edu.ua
}

https://doi.org/10.23939/ep2019.04.212

Received: 24.10 .2019

(C) Dudar T., 2019

\begin{abstract}
This research aims to present and analyze the territories of uranium mining and milling facilities of Ukraine from the point of "legacy sites" view. The territory of approximately $246 \mathrm{~km}$ long and $26 \mathrm{~km}$ wide where uranium legacy sites are located was first outlined and considered according to the developed classification. Further steps to explore this topic using remote sensing technique are indicated.
\end{abstract}

Key words: uranium legacy site, uranium mining and milling facilities, underground mining, in situ leaching

\section{Introduction}

The concept of "uranium legacy sites". The rise of environmental awareness in the world at the end of the last century led to the decommissioning and closure of mining facilities in developed countries, including uranium mines. In the 1990s, the first two major uranium legacy remediation programs, led by the US Department of Energy (DOE) and German Federal Ministry of Economy (BMWi), emerged. The first meeting of experts from both countries took place in 1993 in the USA. Representatives from other uranium mining countries soon joined them, and a Uranium Mining Remediation Exchange Group (UMREG) was formed to share experience on the uranium legacy sites remediation and management.

At a global level, the concept of "radiation legacy sites" - the legacy of radioactively contaminated territories - has been further developed, in particular at the International Meeting in Norway, 2017 [1]. There are many definitions of "radiation legacy sites" and/or "uranium legacy sites", but two key points have to be available - the areas where the level of radioactivity exceeds the background on the one hand, and activities on their restoration have not been completed or have not been carried out at all on the other hand. These are areas contaminated by anthropogenic activity in the past "affected by past practices" that require monitoring with further land reclamation (IAEA, 2016) [2].

Europe's uranium legacy sites. Uranium mining in Europe during the 20th century left a legacy of contaminated territories where the uranium mining (underground and open/quarry or underground in situ leaching - ISL) and processing of uranium raw materials used to take place. Most European countries have stopped their uranium mining and milling activities. Since the late 1980s, considerable effort and resources have been invested by the European Union Member States in dealing with the legacies and liabilities from their former uranium mining activities. Currently, such territories fall in the scope of European Basic Safety Standards (BSS - EU Directive 59/2013) as radiation hazardous areas that require certain measures to address possible environmental remediation. This applies to twelve European countries (not including the eastern countries of the former USSR) where such territories exist and are in the process of being reclaimed or have been fully or partially reclaimed. They are Bulgaria, Estonia, Spain, Germany, Poland, Portugal, Romania, Slovenia, Hungary, France, Czech Republic, and Sweden [3-4].

\section{Challenge problem: uranium legacy sites}

Uranium legacy sites in Ukraine. Ukraine as a uranium mining country having similar legacy sites is not 
usually considered in numerous relevant publications (IAEA, UMREG, etc.). We are not supposed here to analyze why but we would definitely like to draw your attention to uranium mining and milling facilities legacy sites in Ukraine.

This research aims to present the territories of uranium mining and milling facilities in Ukraine from the point of "legacy sites" view that have not been considered in Ukraine yet. All our facilities were operated and still operate according to the standards that are not consistent with the level of protection that would be required nowadays and currently fall in the BSS scope as existing situations of radiation exposure.

We have first outlined the territory of approximately $246 \mathrm{~km}$ long and $26 \mathrm{~km}$ wide where uranium mining and milling facilities are located (Fig. 1, $a-b$ ) according to classification developed and first proposed in [5-6], (Table 1). As it is seen from Figure 1, all the identified sites fall into the central part of the Ukrainian Shield where the majority of discovered uranium deposits are located.
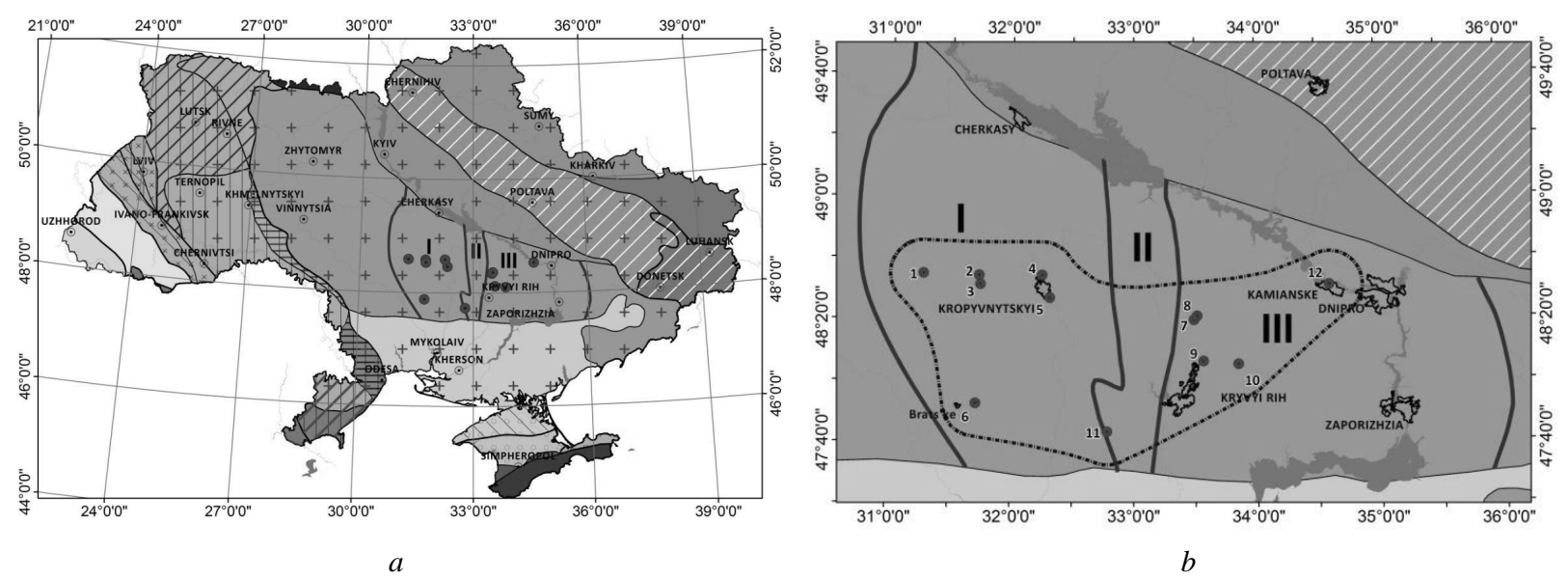

Fig. 1. Location of uranium legacy sites in the Central part of the Ukrainian Shield. Geoblocks of the Ukrainian Shield: I - Kirovogradskyi; II - Ingulskyi; III- Prydniprovskyi

Table 1

Uranium mining and milling facilities legacy sites of Ukraine

\begin{tabular}{|c|c|c|}
\hline \multicolumn{3}{|c|}{ Legacy sites of depleted uranium deposits } \\
\hline Name of legacy site & Location & Notes \\
\hline Pervomaiske deposit & Kirovogradskyi Block of Ukrainian Shield & Depleted through underground mining \\
\hline Zhovtorichenske deposit & Kirovogradskyi Block of Ukrainian Shield & Depleted through underground mining \\
\hline Devladivske deposit & Southern Slope of Ukrainian Shield & Depleted through underground leaching \\
\hline Bratske deposit & Southern Slope of Ukrainian Shield & Depleted through underground leaching \\
\hline \multicolumn{3}{|c|}{ Legacy sites of operating uranium mines } \\
\hline Ingulska mine & Vil. Neopalymivka, Kirovogradska obl. & $\begin{array}{c}\text { Operates two deposits - } \\
\text { Michyrinske and Tsentralne }\end{array}$ \\
\hline Smolinska mine & Settl. Smolino, Kirovogradska oblast & Operates the Vatutinske deposit \\
\hline Novokostyantynivska mine & Vil. Oleksiivka, Kirovogradska oblast & Operates Novokostyantynivske deposit \\
\hline \multicolumn{2}{|c|}{ Legacy sites of milling facilities } \\
\hline Prydniprovskyi & $\begin{array}{c}\text { Town of Kamianske, } \\
\text { Dnipropetrovska obl. }\end{array}$ & Closed in 1990, waiting for remediation \\
\hline Chemical Plant & Town of Zhovti Vody, & Operating facilities \\
\hline Zhovti Vody “Skhid GZK" & Dnipropetrovska obl. & \\
\hline
\end{tabular}

\section{Presentation of allocated uranium legacy sites}

\subsection{Legacy sites of depleted uranium deposits (through underground mining)}

The uranium ore reserves within these sites were depleted long ago. However, the environmental consequences for the territories, affected by past mining practices, remained for the next generations. This is due to a number of reasons, among which are the immaturity of the used technological processes and lack of environmental safety standards. The practical decision to bring the territories to an environmentally safe condition is constrained primarily due to a lack of planning and implementation of long-term environmental restoration programs. 
Uranium Legacy Site of the Pervomaiske deposit (iron-carbonate-uranium ore) is shown in Fig. 2, a. The deposit itself was discovered right after the war in 1945 in the northern part of the Kryvyi Rih city. At that time, it was the largest uranium deposit in the Soviet Union. Uranium ores were depleted in 1968, but the mining itself was still being continued to produce rich iron ore within the site.

Uranium Legacy Site the Zhovtorichenske deposit (albite-uranium, sulphide-pitchblende, and malaconapatite ores) is shown in Fig. 2, $b$. It was discovered in the following 1946, after a thorough radioactivity survey of all the mines in the Kryvyi Rih basin operating at that time. Commercial mining within this ore field began in the early 1950s, and in the early 1990s (for almost forty years!), uranium ore has been depleted to a depth of $1.5 \mathrm{~km}$. In 1946, the deposit was estimated as a high-grade uranium deposit and commercial development began in the early 1950s. In the 1990s, the uranium ores were almost exhausted to a depth of $1.5 \mathrm{~km}$, but complex rare metal and rare earth ores were discovered and explored in the upper horizons. However, the extraction of the rare earth ores was halted when the shafts had been flooded.

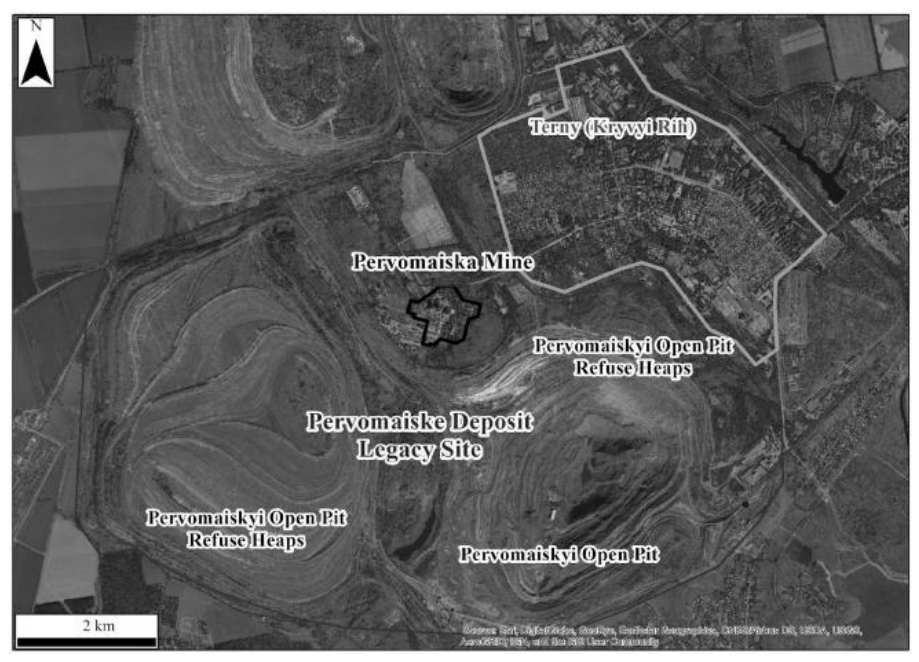

$a$

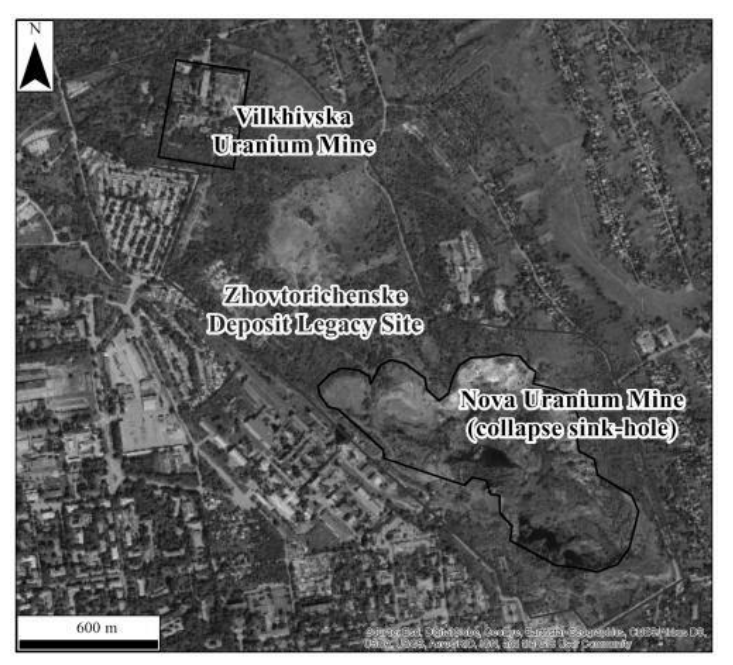

$b$

Fig. 2. Legacy sites of depleted uranium deposits (through underground mining) $\mathrm{a}$ - Pervomaiske deposit site; $\mathrm{b}$ - Zhovtorichenske deposit site

\subsection{Legacy sites of depleted uranium deposits (through underground in situ leaching)}

The Devladivske and Bratske deposits legacy sites have already been recultivated (Fig. 3, $a, b, c$, and $d$ ). Nevertheless, recultivation did not lead to the environmentally safe condition of these sites. It was demonstrated in one of the recent research carried out under the EU support by young experts from the Ukrainian NGOs [7].

Uranium ores were found here in the coalificated sand and clay strata of the Buchakska suite overlain by the Kyiv clays, which forms an artesian aquifer in the production horizon. The Devladivske deposit was discovered northeast of the city of Kryvyi Rih when prospecting for nickel in the eocene lignite deposits in 1955. Research and field works on possible uranium in situ leaching (ISL) within the site started in 1962. Commercial operation of the Devladivske ore field lasted from 1967 till 1983 (for almost17 years!). In general, more, than twenty uranium occurrences were discovered and investigated in the Dnieper Basin. All of them are localized in the flooded sedimentary carbonaceous sandy-clay rocks of the Buchakska suite and have a number of factors favourable for the in situ leaching mining. These factors are shallow depth of ore (from the first to $80-100 \mathrm{~m}$ ), sufficient water saturation of ore horizons and acceptable geo-technological parameters for uranium leaching. Commercial operation of the Bratske ore field lasted from 1972 till 1983 (for almost11 years).

The interest in this region regarding the uranium ISL mining is still ongoing. It would be very advisable to use the experience gained in the other uranium regions worldwide to plan future remediation activities within the sites. After all, it is about launching sulfuric acid solutions into aquifers, closely located to the surface in densely populated areas. 


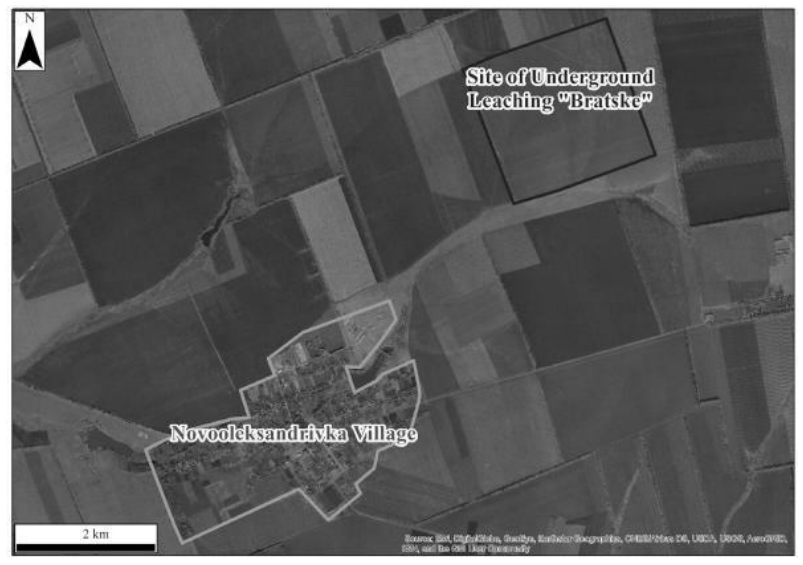

$a$

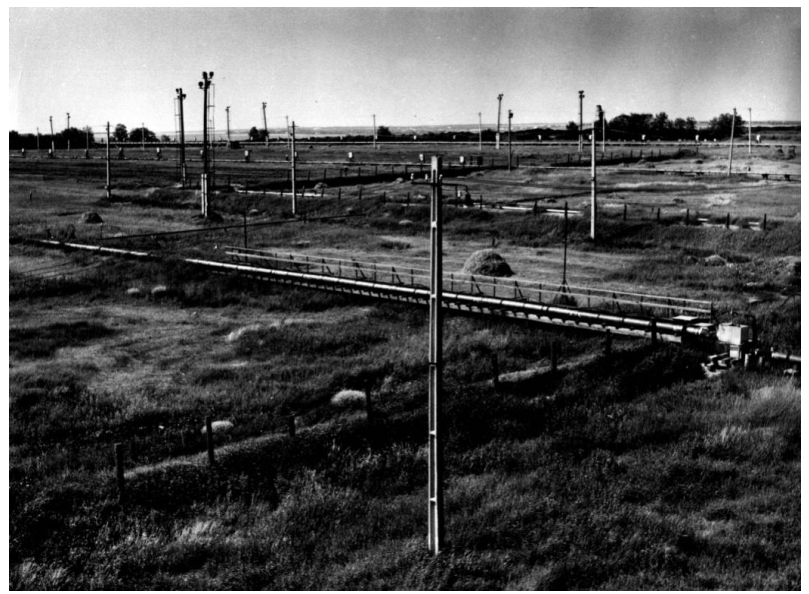

$c$

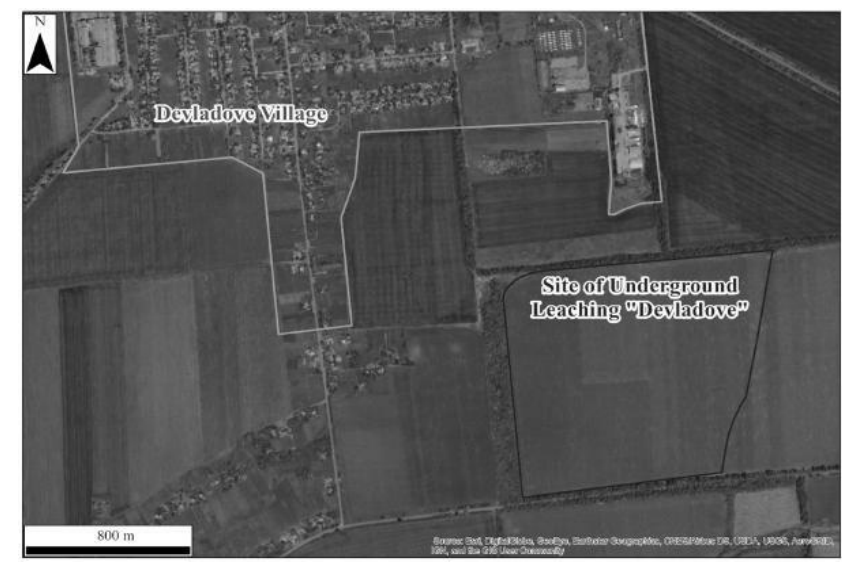

$b$

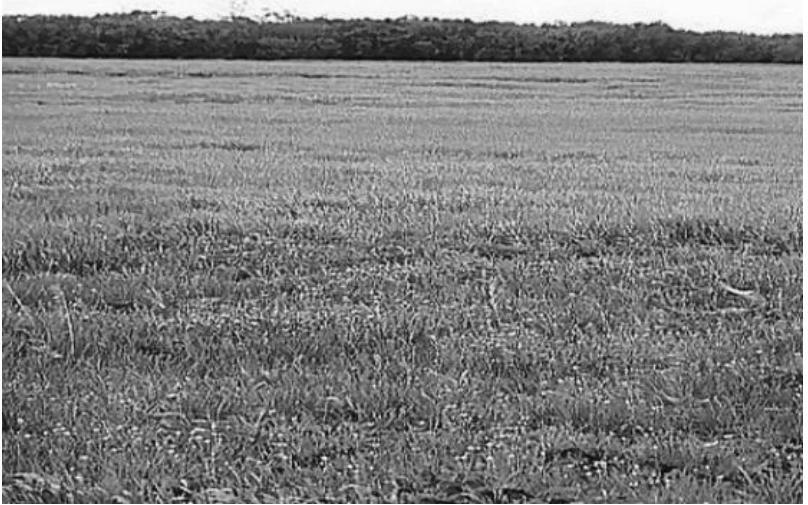

$d$

Fig. 3. Legacy sites of depleted uranium deposits (through underground in situ leaching) $\mathrm{a}$ - Bratske deposit site; $\mathrm{b}$ - Devladivske deposit site;

Bratske deposit 1970, geotechnological field (c); after recultivation, 2010 (d)

\subsection{Legacy sites of operating uranium mines}

In the $1970 \mathrm{~s}$, the center of the uranium industry in Ukraine moved to the Kirovogradska oblast, where the Michurinske and the Vatutinske uranium deposits were put into operation. The development of these deposits continues to the present time. A well-known state-owned enterprise Eastern Mining and Ore Dressing Plant (SkhidGZK) is the biggest in Europe and the only enterprise in Ukraine where uranium ores are extracted and processed, and uranium oxide concentrate is produced. It currently operates three uranium mines. The Ingulska mine is located eight $\mathrm{km}$ southeast of the city of Kropyvnytskyi; the village of Neopalimivka, the Smolinska and the Novokostyantynivska mines are allocated respectively near the villages of Berezivka and Oleksiivka of the Malovysky district of the Kirovogradska oblast (Fig. 4, $a, b, c$ ).

Nowadays, there is a developed infrastructure for uranium extraction and concentrate production in the country. The developing fields have uranium ore bodies of relatively large sizes and are characterized by high strength of uranium-bearing rocks. It allows us to use stoppings of high-volume and mine workings - without a support setting. The deposits can also be developed by applying relatively simple radiation protection measures due to the low content of uranium in ores. All these facts make the Ukrainian ore deposits competitive on the uranium market.

In most countries, the territories, where uranium mining and/or processing takes place, are not referred as to uranium legacy sites. However, we would insist on considering them in the context of legacies, since for long-term development of fields, they have acquired all the signs of radioactively contamination sites due to active anthropogenic activities, and require monitoring with further land reclamation procedures.

According to the data published by the Ukrainian Nuclear Forum Association [8], for more than 50 years, nearly 500 kilometers of mining have been completed at the Ingulsk mine, and 6.6 thousand kilometers of wells have been drilled. For more than 45 years of the 
Smolinska mine development, 267 kilometers of mining were completed, 6.3 thousand kilometers of wells were drilled, and almost 28 million tons of ore was mined. At

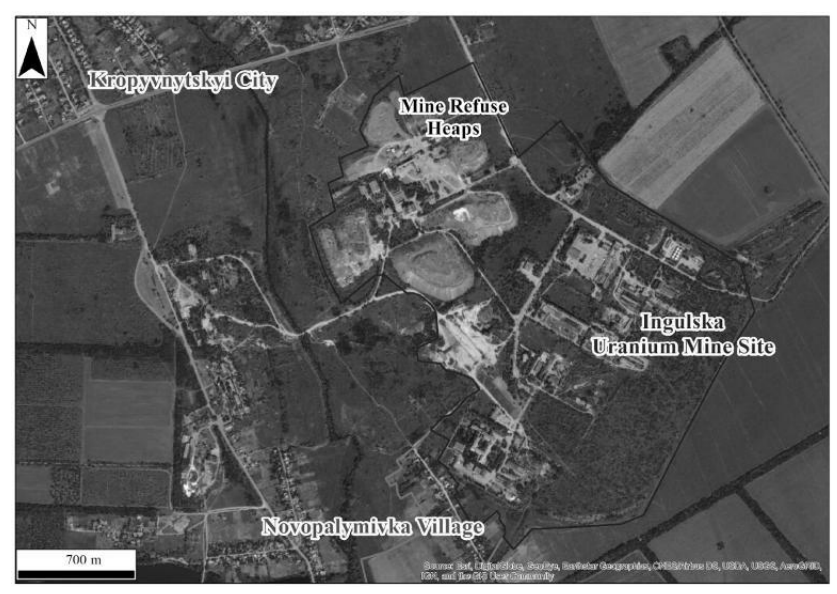

$a$ the Novokostyantynivska mine, $1 \mathrm{mln}$ tons of ore was extracted at the planned capacity - up to $2.5 \mathrm{mln}$ tons per year.
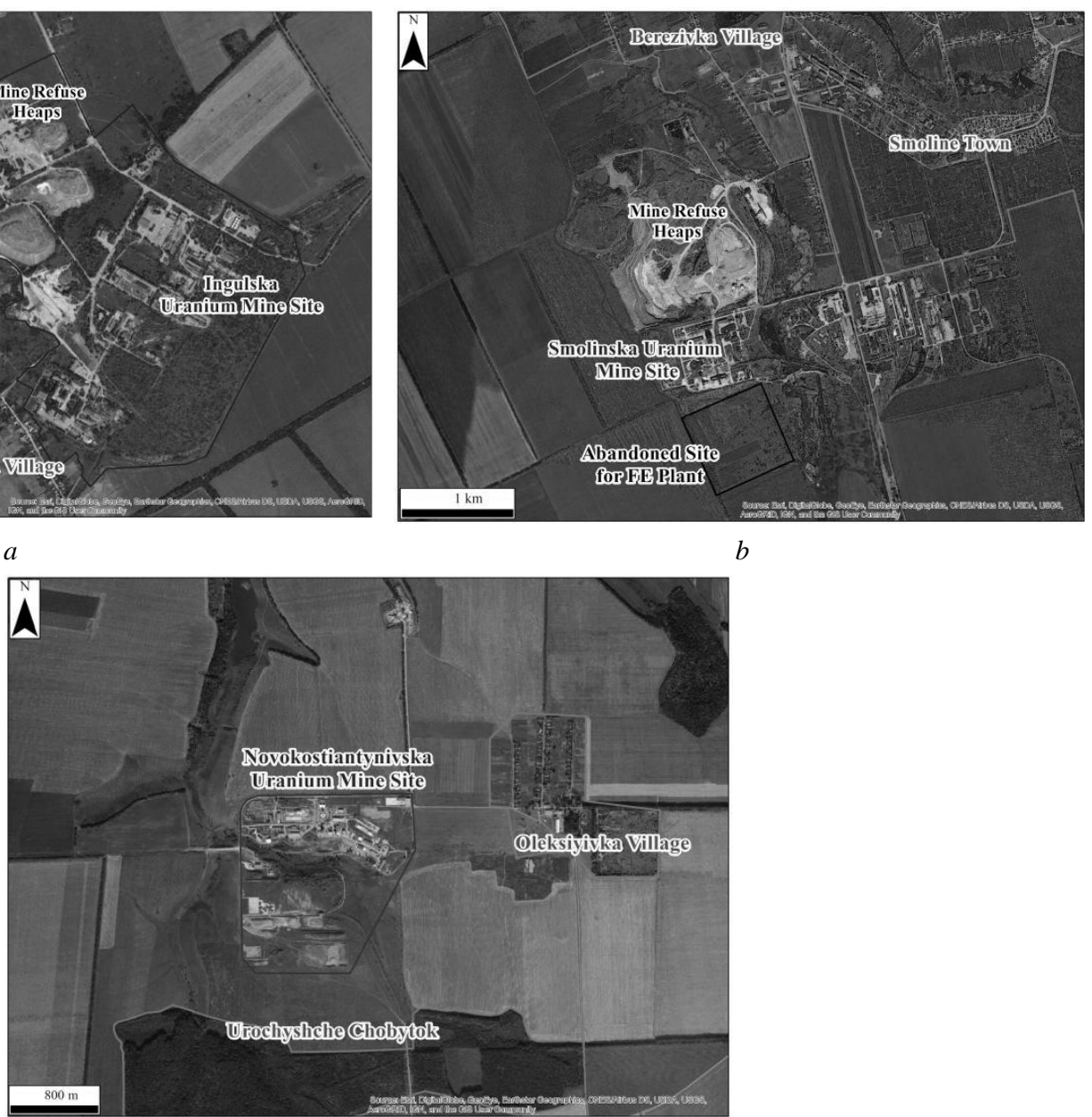

$c$

Fig. 4. Location of the operating uranium mines sites:

a) Ingulska; b) Smolinska and c) Novokostyantynivska mines

\subsection{Uranium milling facilities legacy sites}

As mentioned above, the state-owned enterprise SkhidGZK performs all works on the extraction and processing of uranium ores in Ukraine. Uranium concentrate is obtained at the Hydrometallurgical Plant (HMP) in the town of Zhovti Vody from mixed ore from four active fields since these ores are of the same genetic type and similar in technology to uranium extraction. The tailings ponds of the existing HMP are located on an area of 256 hectares with an average waste activity of $75 \mathrm{~Bq} / \mathrm{h}$ (according to [9]. Two tailing ponds are considered: the depleted quarry of brown iron ore $(B I O)$ and the Balka Shcherbakivska (Fig. 5).

The $B I O$ tailing pond is located on the northern outskirts of the town. The quarry was used for waste storage without special anti-filtration devices. The tailing material, which is the waste of uranium ore processing, was stored in the period from 1964 to 1995 by hydraulic fill. Currently, most of the tailing surface is covered with an insulating layer of soil, and the remaining part has a pond that is used as a reserve tank. The total activity of the assembled material is about $27.000 \mathrm{Ki}$. The area of the tailing is 55.6 hectares, the volume of solid waste is 12.4 million $\mathrm{m}^{3}$.

The Balka Shcherbakivska tailing pond, located $1.5 \mathrm{~km}$ south of the town, consists of two sections: "old" and "new". The "old" section of about 100 ha is used as a reserve, while the "new" section continues to be filled. Dust particles of the tailing pond are a source of radioactive air contamination of the southern part of the town in summer. Radon is released from both tailings, which, due to diffusion and transfer by the wind, which results in an increase in man-made radiation background. 


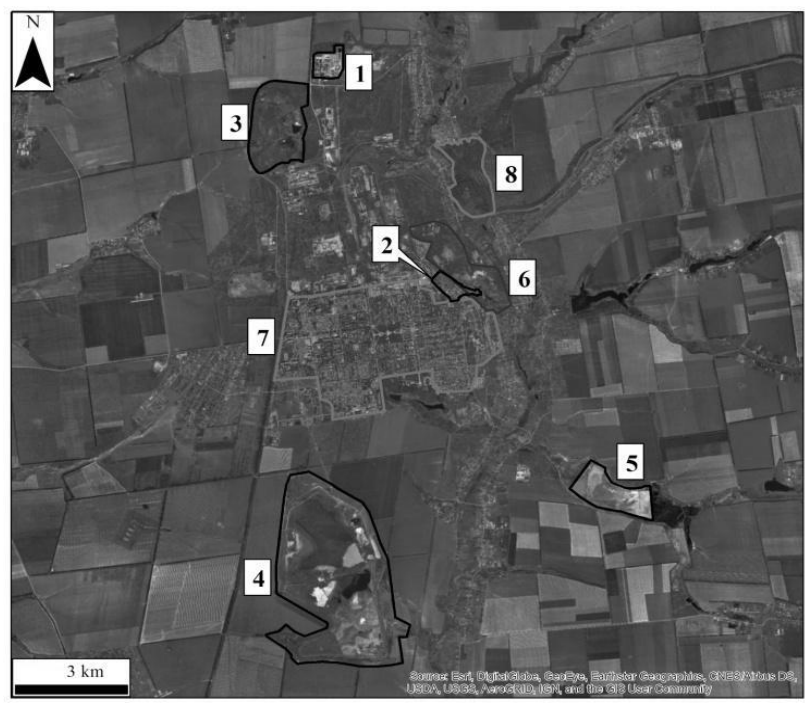

Fig. 5. Mining and milling facilities legacy sites in Zhovti Vody:

1. Sulfuric acid plant; 2. HMP - Hydro Metallurgical Plant;

3. Tailing BIO - quarry of brown iron ore;

4. Tailing Balka Shcherbakivska; 5. Tailing HMP;

6. Zhovtorichenske deposit legacy site;

7. Residential area of Zhovti Vody town; 8. Krasnokuskyi Forest

The Pridneprovskyi Chemical Plant (PChP) was one of the largest uranium ore processing companies in the former USSR from 1949 to 1991 (for more, than 40 years). It processed uranium ores from all over the country, as well as from Eastern Europe. The complicated production complex consisted of facilities for storage and sorting of ores, system of their transportation, grinding shops, acid and soda leaching shops, extraction shops by methods of radiochemistry and hydrometallurgy, storage facilities for residues of extraction production (tails) and low-level production waste, as well as other sites located on the territory of almost 300 ha. The territory of the former PChP is recognized as "a heavy legacy after the collapse of the USSR", "the territory of man-made disasters" [10]. Most facilities are not operated; they remain contaminated and cause damage to the environment, staff and the public. According to the surveys, the leakage of radiation-contaminated groundwater up to the river of Konoplyanka and the Dnieper was revealed. Some engineering structures of the tailings are in a critical condition, which can lead to emergencies.

The PChP legacy site is monitored at the national level. The risks of the impact of technological waste tailings on human health and the environment were assessed as a result of international cooperation; methods (methodology) of remediation and a special-purpose program for the period of 2018-2022 were developed. However, the process of rehabilitation is very complicated and lengthy (15-20 years are being considered). That is why, international cooperation, as well as important dialogues with local authorities, the public, regulatory bodies, etc. are becoming more relevant.

Uranium mining and processing companies in the EU countries are actively developing programs of international technical cooperation aimed at assisting in the implementation of rehabilitation projects. The analysis shows that the effectiveness of such tasks depends largely on the availability of appropriate national environmental security strategies, regulations and regulatory mechanisms, as well as experience in managing such projects in accordance with international standards.

\subsection{Environmental consequences}

As to environmental consequences associated with uranium mining and milling facilities legacy sites - all this is about technologically enhanced sources of natural radiation which is becoming a source of priority concern for the local authorities and the public. Features of environmental impact are due to the receipt together with the waste of radioisotopes of three radioactive families uranium -238 , uranium-235, and thorium-232. Radioactivity is mainly associated with the uranium- 238 family. The level of radioactivity of the waste is different for different fields and depends mainly on the initial content of uranium in the ore, the physical and chemical properties of the ores and host rocks, the meteorological properties of the terrain, as well as the activity of geochemical processes occurring at the deposit before and during its development. It is a matter of natural leaching, which causes the formation of different ratios of uranium with the products of its decay.

In most modern sites, the radioactive contamination above the background can be traced up to $700 \mathrm{~m}$ and more from the main source. This is caused by mechanical losses of uranium-containing substances, diffuse contamination of soil deposited by radioactive dust and aerosols that occur as a result of the operation of stock piles and refuse heaps, roads and railways.

A severe source of contamination (atmospheric air, ground and surface water, soil, vegetation) is associated with the GMP and its tailings. In the processing of uranium ore, about $14 \%$ of total activity goes to uranium concentrate, which contains $90 \%$ of uranium. After the decay of short-lived subsidiary products, about $70 \%$ of the initial activity caused by ${ }^{230} \mathrm{Th}$ and the products of its decay is left.

Due to the fact that one ton of ore containing $1 \mathrm{~kg}$ of uranium has approximately $0.15 \mathrm{GBq}$ of uranium-238 and its decay products, approximately $0.1 \mathrm{GBq}$ of radioactive products, i.e. $100 \mathrm{~Bq}$, is received after the 
extraction of uranium with each ton of waste. According to research [9], the average activity of waste at the tailing ponds (of 542 ha total areas) of ore processing plants (milling facilities) in Ukraine is $70 \mathrm{~Bq} / \mathrm{g}$.

\section{Conclusion}

Uranium legacy sites in Ukraine, where mining and milling facilities were operated or are being currently operated, and where technologically enhanced sources of natural radiation are available were considered from the point of "legacy sites" view. The area of approximately $246 \mathrm{~km}$ long and $26 \mathrm{~km}$ wide where uranium facilities are located was outlined according to the developed classification and nine uranium mining and milling facilities sites were described.

Currently, such territories fall within the scope of the European Safety Standards (BSS - EU Directive 59/2013) as radiation hazardous areas that require some action on possible ways of ecological reclamation.

The described sites require the development and implementation of specific measures for their rehabilitation. Further research of the outlined territory is supposed using the remote sensing technique such as land cover change assessment over the whole territory as well as over each particular site (nine altogether); terrain geodynamics mapping using last 5-year time series of Sentinel-1 satellite radar interferometry, and others. This research is expected to get additional knowledge about the territory affected by the long-term past and present uranium mining and milling activities.

Such activities require considerable financial support and fruitful cooperation between governmental institutions (including research institutions), international organizations, SE "SkhidGZK", local self-government authorities, and non-governmental organizations.

\section{References}

[1] Regulatory Supervision of Legacy Sites: The Process from Recognition to Resolution. Report of an international workshop Lillehammer, 21-23 November 2017.

[2] IAEA, 2005. Environmental contamination from uranium production facilities and their remediation. In: Proc. an Int. Work. Held Lisbon, Port. 11-13 Febr.2004.

[3] Miloš René (December 20th 2017). History of Uranium Mining in Central Europe, Uranium - Safety, Resources, Separation and Thermodynamic Calculation, Nasser S. Awwad, Intech Open, DOI:10.5772/intechopen.71962.

[4] Hähne R, Murphy S, Vrijen J. J., "State and prospects of closure and remediation of tailings deposits from uranium ore processing and heap leaching in Europe" Vienna, Austria: IAEA, 2011.

[5] Dudar T. V., Stankevich S.A. et al.: Environmental safety of the territory of uranium mining and milling legacy in Ukraine. VII All-round Ukrainian and international participation Environmental Congress (Ecology-2019), September 25-27, 2019. Collection of research papers. Vinnitsya: VNTU? 2019/ P/51.

[6] Dudar T. V. Uranova spadshchina Ukrainy: ecologichni naslidky. Ekilogichna bezpeka derzavy: problem I shlyakhy vurishennya. Materialy XV miznarodnoi konferentsii. 9-13 September 2019. Kharkiv. P. 157-161.

[7] Balyan O., Bulgakova M. Yeremenko I. Report "Ecologichna bezpeka uranovyh shakht". Available at: http://atom.org.ua/wp-content/2016/03/Uran_mines_ Ukraine_report.pdf

[8] Podulyakh S. Yaderne sertse Ukrainy. Atomprom Ukrainy. No. 2, 2017. P. 6-8.

[9] Kovalenko G. D. Radioecologiya Ukrainy: monographiya. Izdanie 3, pererab. I dopoln. Kharkiv.: INZEK, 2013. $344 \mathrm{p}$.

[10] Ryazantsev V. Terytoriya tekhnogennogo lykha. Atomprom Ukrainy. No. 2, 2017. P. 20-24. 